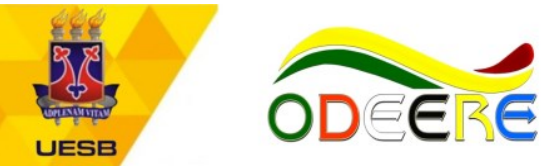

\title{
Relações étnico-raciais e de gênero em debate nos Ateliês de Pesquisa: (Re)invenções nas Práticas Pedagógicas
}

\author{
Marleide Alves de Oliveira Medeiros ${ }^{1}$ ii \\ Secrataria da Educação do Estado da Bahia
}

Vaneza Oliveira de Souza ${ }^{2}$

Secrataria da Educação do Estado da Bahia

Ana Lúcia Gomes da Silva ${ }^{3}$ (D)

Universidade do Estado da Bahia

\section{Artigos livres | Free articles | Articulos libres \\ DOI do artigo: 10.22481/odeere.v6i01.8581}

\begin{abstract}
RESUMO
Este artigo tem como objetivo discutir os principais resultados apresentados pelas pesquisas: "Relações étnico-raciais e de gênero no contexto das práticas pedagógicas: escrevivências e (re)invenções na educação básica" e a pesquisa "Ensino de História e Cultura Afro-brasileira, Africana e Identidade: desafios e implicações nas Práticas pedagógicas" ", e suas implicações para as práticas pedagógicas na educação básica com ênfase nas relações étnico-raciais e de gênero, apontando ainda para a importância da Interseccionalidade como chave-de leitura dos marcadores sociais das diferenças emergentes em campo, como sexualidade, deficiências e gênero, considerando a pesquisa guarda-chuva e os subprojetos de iniciação científica a ela veiculados. Dialogamos com os métodos adotados nas pesquisas, a etnoescrevivência e a pesquisa ação colaborativa, tomando os Ateliês de Pesquisa (APs) como dispositivo de construção de dados e intervenção, que possibilitou a construção de um movimento (auto)formativo e coautoral, pautado na colaboração e na reflexão sobre a prática. As discussões teóricas dialogam principalmente com hooks (2017); Lima (2015); Pimenta (2005); Silva e Costa (2020) e outros/as autores/as. Os resultados apontaram que ao tomar como centralidade as narrativas da experiência docente e suas histórias de vida no entrelace do desenvolvimento profissional, os APs provocaram deslocamentos nos processos formativos com os temas raça e gênero, produzindo reflexão e alteração nas práticas pedagógicas. Demonstraram ainda, que não basta ser colaborador da pesquisa para que a cocriação e coautoria se estabeleçam, é fundamental que o ethos da confiança, a relação ética e horizontal seja construída ao longo do processo, haja vista que o modus operandi dos Ateliês de Pesquisa prima pela horizontalidade, invenção e experiência ancoradas no real do cotidiano escolar como propulsoras da produção do conhecimento pedagógico considerado como conhecimento científico do campo da docência.
\end{abstract}

Palavras-chave: Relações de raça e gênero. Narrativas docentes. Práticas pedagógicas. Ateliês de

\footnotetext{
1 Mestra em Educação e Diversidade (MPED \UNEB). Especialista em Mídias na Educação (UESB), e em Métodos e Técnicas de Ensino (UNIVERSO). Licenciada em História pela (UNEB-Campus IV). Docente da educação básica, realiza estudos na área de educação com enfoque nos temas: formação docente e relações étnico raciais. Pesquisadora do Grupo de Pesquisa Diversidade, Discursos, Formação na Educação Básica e superior (DIFEBA/UNEB). E-mail: marleidemedeiros35@gmail.com

2 Mestra em Educação e Diversidade (MPED/UNEB). Especialista em Neuropedagogia e Psicanálise. Licenciada em Letras com Inglês pela (UNEB) e em Pedagogia (UNOPAR). Pesquisadora do Grupo de Pesquisa (DIFEBA-UNEB). Membra do Coletivo Liberta Preta (UNEB, Seabra). Professora da Educação Básica e pesquisadora das relações étnico-raciais e de gênero. E-mail: vanessas.rita@hotmail.com

3 Doutora e Mestra em Educação pela (UFBA). Pós-doutora em Educação (UFTM). Professora titular do Departamento de Ciências Humanas da (UNEB), campus IV. Docente do Curso de Letras Vernáculas e do Programa de Pós-Graduação em Educação e Diversidade (PPED), UNEB. Líder do grupo de pesquisa Diversidade, Discursos, Formação na Educação Básica e Superior (DIFEBA/UNEB). Pesquisadora e orientadora de temas de pesquisa sobre formação de professores para/com a diversidade, relações de gênero e étnico-raciais. E-mail: analucias12@gmail.com

${ }^{4}$ As pesquisas não receberam financiamento.
} 
Medeiros, M. A. O., de Souza, V. O., da Silva, A. L. G., Relações étnico-raciais e de gênero em debate nos Ateliês de Pesquisa: (Re)invenções nas Práticas Pedagógicas. ODEERE, v. 6, n. 01 , jan./jun., p. 311-341, 2021. https://doi.org/10.22481/odeere.v6i01.8581

Pesquisa. Educação Básica.

\section{Ethnic-racial and gender relations in debate in Research Workshops: (Re)inventions in Pedagogical Practices ABSTRACT}

This article aims to discuss the main results presented by the research "Ethnic-racial and gender relations in the context of pedagogical practices: experiences and (re) inventions in basic education" and the research "Teaching of Afro-Brazilian and African History and Culture and Identity: challenges and implications in pedagogical practices", and its implications for pedagogical practices in basic education with emphasis on ethnic-racial and gender relations, also pointing to the importance of intersectionality as a key to reading the social markers of differences emerging in the field, such as sexuality, disabilities, and gender, considering the umbrella research and the scientific initiation subprojects linked to it. The theoretical discussions dialogue mainly with hooks (2017); Lima (2015); Pimenta (2005); Silva and Costa (2020) and other authors. The results indicated that by taking as centrality the narratives of the teaching experience and their life stories in the intertwining of professional development, the APs provoked displacements in the formative processes with the themes of race and gender, producing reflection and change in the pedagogical practices. They also showed that it is not enough to be a collaborator in the research for the co-creation and co-authorship to be established, it is essential that the ethos of trust, the ethical and horizontal relationship is built throughout the process, given that the modus operandi of the Research Workshops excels in horizontality, invention and experience anchored in the real of everyday school life as drivers for the production of pedagogical knowledge considered as scientific knowledge in the field of teaching.

Keywords: Race and gender relations. Teachers' narratives. Pedagogical practices. Research Workshops. Basic Education.

\section{Submetido em: 30 de abr. de 2021 | Aceito em: 17 de jun. de 2021}

\section{Introdução}

Este texto apresenta os resultados de duas pesquisas desenvolvidas no âmbito do Programa de Pós-Graduação em Educação e Diversidade do Mestrado Profissional em Educação e Diversidade (MPED), na Universidade do Estado da Bahia, campus IV, bem como seus desdobramentos na interface educação básica e universidade.

A pesquisa "Relações étnico-raciais e de gênero no contexto das práticas pedagógicas: escrevivências e (re)invenções da educação básica", de autoria de Vaneza Oliveira de Souza (2020), investigou como se configuram as discussões sobre raça e gênero em uma escola de ensino médio em Iraquara-BA e suas principais implicações nas práticas pedagógicas. A pesquisa "Ensino de História e Cultura Afro-brasileira, Africana e Identidade: desafios e implicações nas Práticas pedagógicas", de autoria de Marleide de Oliveira Medeiros (2018), investigou a efetivação da Lei 10.639/03 sobre a obrigatoriedade do ensino de História e Cultura Afro-brasileira e Africana e as implicações para as práticas pedagógicas, no Colégio Gilberto Dias Miranda (COMUJA), na cidade de Jacobina-Bahia.

As pesquisas aqui em diálogo, foram desenvolvidas em distintos lócus do raio 
Medeiros, M. A. O., de Souza, V. O., da Silva, A. L. G., Relações étnico-raciais e de gênero em debate nos Ateliês de Pesquisa: (Re)invenções nas Práticas Pedagógicas. ODEERE, v. 6, n. 01 , jan./jun., p. 311-341, 2021. https://doi.org/10.22481/odeere.v6i01.8581

de abrangência do Estado da Bahia, no período entre 2016 e 2020. Os resultados principais apontaram que ao tomar como centralidade as narrativas da experiência docente e suas histórias de vida no entrelace do desenvolvimento profissional, os Ateliês de Pesquisa (APs) provocaram deslocamentos nos processos formativos com os temas raça e gênero, produzindo reflexão e alteração nas práticas pedagógicas. Os desdobramentos das pesquisas contribuem para ampliar - caminho formativo em rede a partir da formação do coletivo de estudantes/mulheres na escola CEMTL e dos Ciclos Formativos com os/as docentes colaboradores/as do COMUJA.

As investigações estão vinculadas à pesquisa guarda-chuva "Profissão docente na Educação Básica no Piemonte da Diamantina: formação, contextos de diversidade e práticas pedagógicas". Esta, por sua vez, apresenta os dados emergentes dos subprojetos de iniciação científica cujos títulos são: "Práticas Pedagógicas na educação básica de Jacobina-Bahia em contextos de diversidade: interseccionalidades e recursos multimídias, de autoria de Fernando Macedo da Silva (2019), "Intrerseccionalidade entre surdez e sexualidade: um estudo sobre a construção da identidade surda na educação básica de JacobinaBA", de Ádina Nunes Rios Silva (2020), e a pesquisa "Gênero e formação docente: cartografias da prática pedagógica do professor de história em contextos de diversidade na educação básica de Jacobina- BA", de Renata Saane de Souza Cruz (2020).

Na fase de desdobramento pós-defesa de mestrado, a pesquisa de autoria de Marleide de Oliveira Medeiros (2020), foi incorporada aos Ateliês de Pesquisa da pesquisa matricial, por ter sido desenvolvida no mesmo lócus onde esta foi realizada. O objetivo central foi ampliar as ações em rede colaborativa, acerca da docência como profissão em contextos de diversidade e ainda aprofundar o uso do dispositivo Ateliê de Pesquisa e a temática étnico-racial como ação central das práticas pedagógicas; esta última, aqui compreendida como princípio formativo e epistêmico que interroga a docência e nos atravessa em nossos marcadores das diferenças, além de tomar a escola como lócus da formação, considerando as demandas do coletivo em todas as pesquisas aqui analisadas.

Este artigo busca responder a seguinte questão: quais os principais resultados das pesquisas que tomam como objeto de estudo as relações étnico-raciais na 
Medeiros, M. A. O., de Souza, V. O., da Silva, A. L. G., Relações étnico-raciais e de gênero em debate nos Ateliês de Pesquisa: (Re)invenções nas Práticas Pedagógicas. ODEERE, v. 6, n. 01 , jan./jun., p. 311 -341, 2021. https://doi.org/10.22481/odeere.v6i01.8581

educação, com ênfase nos desdobramentos e acompanhamento do lócus da pesquisa pós-defesa? Nosso objetivo é discutir os principais resultados apresentados pelas investigações em tela e suas implicações para as práticas pedagógicas na educação básica das escolas parceiras da pesquisa, com ênfase nas relações étnicoraciais e de gênero, apontando ainda para a importância da Interseccionalidade como chave de leitura dos marcadores sociais das diferenças emergentes em campo, como sexualidade, deficiências e gênero, considerando a pesquisa guarda-chuva e os subprojetos de iniciação científica a ela veiculados.

Nesta trajetória, dialogamos com os métodos adotados nas pesquisas, a saber, a etnoescrevivência, que tomou como centralidade as narrativas da experiência para compreender processos formativos com os temas raça e gênero, com vistas a produzir reflexão e alteração nas práticas pedagógicas; e a pesquisa ação colaborativa. Ambas as investigações tomaram os Ateliês de Pesquisa (APs) como dispositivo de construção de dados e intervenção, que possibilitou a construção de um movimento (auto)formativo pautado na colaboração e na reflexividade sobre a prática.

Os APs integram um modo de fazer pesquisa pautado na horizontalidade, no fazer com, na escuta e no acolhimento. Universidade e educação básica, pesquisadores/as e colaboradores/as aprendem juntos/as, agenciando a ética do cuidado e o ethos da confiança no processo de interrogação da prática e seus desafios. Como nos apontam Ana Lúcia Gomes da Silva e Váldina Costa (2020), a gênese do Ateliê de Pesquisa se dá a partir do componente curricular Pesquisa Aplicada à Educação I e II (PAE). Entre os anos de 2014 e 2016, foram realizados cinco Ateliês de pesquisa com mestrandos/as do Mestrado Profissional em Educação e Diversidade (MPED) da Universidade do Estado da Bahia (UNEB).

Todos eles foram operacionalizados com objetivos distintos, de acordo com as necessidades formativas dos/as sujeitos/as envolvidos/as. No entanto, tinham em comum, a preocupação com a pesquisa implicada/engajada em educação, seus dispositivos de construção de dados e os processos de construção do conhecimento nela imbricados. Posteriormente, em 2015, os Ateliês de Pesquisa tiveram como desdobramento sua escolha e utilização como dispositivo de pesquisa nos estudos de Mestrado do MPED e Iniciação Científica (IC) da UNEB e Pós-doutorado na Universidade Federal do Triângulo Mineiro (UFTM), em virtude da 
Medeiros, M. A. O., de Souza, V. O., da Silva, A. L. G., Relações étnico-raciais e de gênero em debate nos Ateliês de Pesquisa: (Re)invenções nas Práticas Pedagógicas. ODEERE, v. 6, n. 01 , jan./jun., p. 311-341, 2021. https://doi.org/10.22481/odeere.v6i01.8581

sua concepção ser formativa e auto formativa no processo do/a pesquisador/a.

O passo a passo metodológico operacional, explicitado e utilizado pelos/as pesquisadores/as sobre os Ateliês de Pesquisa não devem ser tomados como um guia, nem supõe a elaboração de um manual a ser seguido, mas a descrição e discussão de opções e encaminhamentos que ao longo do percurso da pesquisa vão sendo delineados, acrescidos de uma postura que se faz necessária desenvolver, assumida, portanto, autoralmente, de quem se aventura nessas modalidades de investigação, na qual nos formamos e autoformamos pesquisadores/as sedentos/as de aprender outros modos de pesquisar em educação.

Cada pesquisa que utilizou o dispositivo Ateliê de Pesquisa o fez de modo cocriador, diferenciado, único, tais quais os/as docentes que delas participaram. Assim, as duas pesquisas apresentam o princípio ético da colaboração e da coautoria, em que os/as participantes são cocriadores/as, sujeitos que produzem conhecimentos de forma horizontalizada e criativa. As discussões teóricas dialogam principalmente com bell hooks 5 (2017); Maria Nazaré de Mota Lima (2015); Pimenta (2005); Ana Lúcia Gomes e Váldina Costa (2020) e outros/as autores/as.

O texto foi estruturado em trilhas narrativas, a saber: Trilha narrativa 1 Conceitos teóricos centrais operados nas pesquisas como chave de leitura da realidade, em que discutimos as implicações dos conceitos e dados produzidos com os/as sujeitos/as da pesquisa. Trilha narrativa 2 - Diálogos metodológicos: aproximações e deslocamentos entre os métodos pesquisa-ação colaborativa e etnoescrevivência, em que as autoras discorrem sobre os métodos de pesquisa adotados para responder à questão investigativa deste texto, bem como seus objetivos centrais, considerando os quadros teóricos em que os métodos se ancoram, assim, como os paradigmas que sustentam as pesquisas apresentadas. $\mathrm{Na}$ trilha narrativa 3 - Experiências com AP's antes e depois da pandemia: resultados centrais, discutimos a reinvenção deste dispositivo no contexto da pandemia, os principais atravessamentos sobre os processos formativos e sobre as práticas pedagógicas, considerando as relações de raça, gênero e outras

\footnotetext{
${ }^{5}$ Pseudônimo usado em letras minúsculas a pedido da própria escritora, Gloria Watkins.
} 
Medeiros, M. A. O., de Souza, V. O., da Silva, A. L. G., Relações étnico-raciais e de gênero em debate nos Ateliês de Pesquisa: (Re)invenções nas Práticas Pedagógicas. ODEERE, v. 6, n. 01 , jan./jun., p. 311-341, 2021. https://doi.org/10.22481/odeere.v6i01.8581

diferenças que emergiram nas narrativas, e os desdobramentos das pesquisas.

E, por fim, as Trilhas finais e as Referências. Trilhas são concebidas neste texto como caminhos e possibilidades de narrar os percursos e resultados das pesquisas, a fim de estabelecermos atalhos, aproximações e distanciamentos que hibridizam o conhecimento sem os fixar, engessar. Antes, abrindo mais e mais trilhas em devir para que outros/as pesquisadores/as, se inspirem e criem as suas de modo inventivo e autoral, inundando o campo educacional de pesquisas que fazem brotar narrativas em que a escrevivência e as histórias de vida balizam a produção do conhecimento como invenção de si e do outro numa comunidade científica de aprendizagem, cujas redes são tecidas com docentes da Universidade e da educação básica de modo horizontalizado.

\section{Trilha narrativa 1 - Conceitos teóricos centrais operados nas pesquisas como chave de leitura da realidade}

Desenvolver práticas pedagógicas antirracistas, antissexistas, antidiscriminatórias é um trabalho desafiador. Fomos socializados/as em instituições (igreja, família, escola e outras) que costumam (re)produzir, naturalizar ou silenciar diante do racismo, do sexismo e outras formas de discriminação. Muitas instituições disseminam o discurso da democracia racial e privilegiaram os modos de ser, viver e conhecer eurocêntricos e hegemônicos que deslegitimam e inferiorizam povos e saberes negros e indígenas (PIRES e MIRANDA, 2015) e constroem relações desiguais de raça, gênero, classe, sexualidade.

A intelectual negra Maria Nazaré Mota de Lima (2015, p.21) discute como a escola continua a difundir "ideias e valores de uma camada que detém o acesso e possui trânsito facilitado nesta cultura, perpetuando-se a segregação entre os que podem e os que não podem estudar, ler, escrever, 'pensar'". Através de práticas pedagógicas e curriculares cotidianas a escola reforça a guetização e naturaliza os lugares de "não acesso, não poder, não saber, não ter, não ser...".

Processos homogeneizadores e fragmentados de escolarização que desconsideram a presença e o valor dos diferentes grupos, reforçam movimentos de exclusões ao separar os estudantes entre as/os que podem e as/os que não podem pensar. Ao supervalorizar grupos privilegiados em detrimento de pessoas 
Medeiros, M. A. O., de Souza, V. O., da Silva, A. L. G., Relações étnico-raciais e de gênero em debate nos Ateliês de Pesquisa: (Re)invenções nas Práticas Pedagógicas. ODEERE, v. 6, n. 01 , jan./jun., p. 311-341, 2021. https://doi.org/10.22481/odeere.v6i01.8581

negras, indígenas, quilombolas, mulheres, lésbicas, trans, reproduzem ou naturalizam situações de desigualdade e discriminação.

Assim como em outros espaços, na escola estamos expostos/as aos trânsitos cotidianos da raça, classe, gênero, sexualidade, de forma interseccional (CRENSHAW, 2002; AKOTIRENE, 2018). Quando grupos de estudantes e educadores/as são simultaneamente afetados/as por tais eixos, suas trajetórias escolares tendem a ser mais desafiadoras, pois em sociedades racistas, sexistas, classistas, Igbtfóbicas, capacitistas, dentre outros, nossos pertencimentos nos empurram para lugares sociais de subalternidade.

O olhar interseccional contribui para compreender a interação das estruturas racistas, patriarcais, classistas, assim como outras formas de opressão que provocam "atropelamentos" simultâneos e geram muitas formas de desigualdades pautadas em tais diferenças (CRENSHAW, 2002; AKOTIRENE, 2018, SOUZA, 2020). Nesse sentido, percebemos que há grupos mais fortemente alvejados por se encontrarem nos cruzamentos das dinâmicas de raça, gênero e poder, que os/as lançam para espaços de pobreza e vulnerabilidade.

Neste texto, tomamos raça como uma categoria que tem dimensão social e política, relacionada à ideia que fundamenta o racismo, uma estrutura de poder e dominação que produz privilégios, desigualdades e violências, em função de características raciais. O racismo contra negros/as no Brasil vai além de aspectos culturais, integrando aspectos físicos, estéticos, corporais (BARROS, 2011; SOUZA, 2020). As estruturas racistas, por sua vez, se cruzam com outras como as patriarcais, construídas a partir do gênero, que concedem privilégios a homens brancos heterossexuais. Relacionamos gênero a construções sociais e históricas, pautadas nas representações de feminilidade, masculinidade e heteronormatividade, que também sustentam relações de poder e produzem desigualdades (LOURO, 1997; SOUZA, 2020).

A sensibilidade interseccional nos alinha ao pensamento antirracista e antissexista, pois interpela a desafiar modelos hegemônicos de produção de conhecimentos que nos querem disciplinadas/os para alimentar ou naturalizar relações racistas, capitalistas e cisheteropatriarcais.

Nesse sentido, compreendemos como práticas pedagógicas antirracistas e antissexistas aquelas planejadas com intencionalidade de desnaturalizar relações 
Medeiros, M. A. O., de Souza, V. O., da Silva, A. L. G., Relações étnico-raciais e de gênero em debate nos Ateliês de Pesquisa: (Re)invenções nas Práticas Pedagógicas. ODEERE, v. 6, n. 01 , jan./jun., p. 311 -341, 2021. https://doi.org/10.22481/odeere.v6i01.8581

de poder e desestabilizar hierarquias de raça e gênero, questionando privilégios e exclusões (CAVALLEIRO, 2020). Inclui reconhecer as assimetrias raciais e de gênero em nossa sociedade, refletir e ter atitude interventiva sobre o racismo, sexismo e suas expressões dentro e fora da escola, romper estereótipos, valorizar saberes de povos negros, quilombolas, indígenas, assim como das mulheres de tais grupos desprivilegiados. Pensar a escola como espaço para descolonizar o pensamento, rasurando dinâmicas de colonialidade nos currículos, material didático, estrutura organizacional, nas relações e práticas cotidianas, a partir de processos formativos que coloquem em pauta os temas raciais e de gênero (SOUZA, 2020).

Para tanto, os processos (auto)formativos em exercício da escola são vistos como momentos de reflexão e ressignificação sobre nossas práticas. Nas pesquisas em discussão neste texto, tomamos a experiência docente como móvel para configurar processos formativos através dos APs, considerando que estudantes e professores/as têm pertencimentos de raça, classe, gênero e outros, e que as práticas pedagógicas são questionadas cotidianamente por essas diferenças.

Os APs são espaços de diálogo e reflexão em que a formação em exercício é pensada a partir da experiência docente como bagagem subjetiva produzida nas interações cotidianas que movem as práticas pedagógicas (SOUZA; MIRANDA; SILVA, 2020). A bagagem de cada docente é concebida como alimento "teóricoempírico", saberes a serem compartilhados no acontecer, no encontro, pois a experiência é vista como produção de conhecimento.

A ambiência de compartilhamento implica sensibilidade, generosidade, desejo e confiança, para expor narrativas sobre nós e nossas histórias e formação, que suscitam possibilidades pedagógicas, novas (re)invenções, e objetiva a tecitura de outros olhares sobre nossas práticas. A experiência como formação é pensada como algo que toca, atravessa e possibilita deslocamentos, amadurecimento e produção de sentidos sobre as relações de raça, gênero e outras presentes no contexto escolar. Essa passagem implica imersão na docência em todos os níveis de ensino, envolvendo-se, tomando parte das dinâmicas escolares, o que exige tempo, a fim de que as ações sejam efetivamente refletidas, no seu processo formativo, como nos aponta Jorge Larrosa, (2001, 2005), possibilidades do estabelecimento de redes de comunicação, colaboração e formação, em que as aprendizagens se articulem de forma intensa nos diversos 
Medeiros, M. A. O., de Souza, V. O., da Silva, A. L. G., Relações étnico-raciais e de gênero em debate nos Ateliês de Pesquisa: (Re)invenções nas Práticas Pedagógicas. ODEERE, v. 6, n. 01 , jan./jun., p. 311-341, 2021. https://doi.org/10.22481/odeere.v6i01.8581

níveis da educação.

Assim, a experiência como formação, abre possibilidades para construir um olhar interseccional sobre as relações e dinâmicas escolares construindo reinvenções na busca por uma educação antirracista, antissexista e antidiscriminatória.

\section{Trilha narrativa 2 - Diálogos metodológicos: aproximações e deslocamentos entre os métodos pesquisa-ação colaborativa e etnoescrevivência}

As investigações foram desenvolvidas a partir dos pressupostos da etnoescrevivência e da pesquisa ação colaborativa, e não se fixam em um paradigma, dialogando com as pesquisas críticas e pós-críticas em movimentos híbridos de aproximações, considerando os quadros teóricos em que os métodos se ancoram. Assim, buscamos esse diálogo para construir um caminho de pesquisa em que a interpretação da realidade, as narrativas dos/as sujeitos/as e suas práticas pedagógicas são os lastros para o enredamento híbrido da tecitura metodológica na pesquisa qualitativa em educação, primando pela experiência, pelas demandas do coletivo e pelas reflexividades produzidas considerando o debruçar-se sobre a socialização, pela partilha e escuta das narrativas docentes.

Tomamos a realidade como um todo de múltiplas relações, problematizando as relações de raça, gênero, assim como classe, sexualidade; discutimos tempos e espaços da escola atual, colocando no campo de investigação as relações de poder na educação, os/as sujeitos/as e suas subjetividades; questionamos conhecimentos, verdades, discursos hegemônicos como processos artificiais de produção de saberes. Nesse viés, questionamos porque alguns conhecimentos são legitimados, interrogamos as "verdades" escolares materializadas nos currículos, livros didáticos, materiais e práticas pedagógicas que muitas vezes reforçam as estruturas do racismo e do patriarcado.

Alinhada a esses princípios, a etnoescrevivência toma a experiência cotidiana como centralidade para compreender o fenômeno investigado, mantendo a perspectiva de problematizar, questionar e intervir sobre a realidade.

Trata-se de uma articulação teórico-metodológica entre etnografia crítica e escrevivência, convocando o coletivo para o protagonismo e cocriação através 
Medeiros, M. A. O., de Souza, V. O., da Silva, A. L. G., Relações étnico-raciais e de gênero em debate nos Ateliês de Pesquisa: (Re)invenções nas Práticas Pedagógicas. ODEERE, v. 6, n. 01 , jan./jun., p. 311-341, 2021. https://doi.org/10.22481/odeere.v6i01.8581

de suas narrativas. Dialogam, pois, em coautoria com as pesquisadoras construindo sentidos de coletividade e provocando inquietações e movimentos de alteração da realidade. É um movimento colaborativo, construído com cumplicidade e confiança a partir da ética do cuidado, que ao falar de si, (re)cria espaços de (re)invenção e coautoria.

O movimento epistêmico da escrevivência, que permeia toda pesquisa de Souza (2020), é uma escrita que narra a vida e as subjetividades construídas e praticadas nos cotidianos. A experiência narrada pelas/os colaboradoras/es e pela professora pesquisadora como mulher negra, objetivaram construir novos sentidos em torno das questões étnico-raciais e de gênero, problematizando e rasurando relações assimétricas de poder, e produzindo mudanças nos discursos e práticas pedagógicas.

Inspirada em Conceição Evaristo (2009), a escrevivência é um método de investigação, de produção de conhecimento e de posicionalidade implicada na construção da pesquisa. Possibilita ampliar o olhar sobre as várias manifestações das negritudes, compreendendo que há diferentes maneiras de ser mulher, de ser negra/o, de ser pessoa. Com esse olhar, abrimos caminhos para pensar a escola como espaço das diferenças, da multiplicidade, da pluralidade e das singularidades (SOUZA, 2020; SOUZA; MIRANDA; SILVA, 2020).

Através das escritas de si os/as docentes (re)elaboram experiências e produzem subjetividades implicadas, um exercício formativo que abre espaço para questionar a si mesmos/as e seu fazer, um movimento de (re)invenção. São reflexões que contribuem para (re)pensar a prática pedagógica, pois além de mobilizar discussões sobre conceitos e metodologias, incorpora dimensões pessoais e profissionais, incluindo aspectos relativos à raça e gênero, contextos que extrapolam o espaço da escola.

Na pesquisa-ação colaborativa, a ação possibilita ao/a participante, assim como também ao/à pesquisador/a, alcançar e produzir conhecimentos por meio da reflexão crítica do seu fazer pedagógico, procurando resolver as demandas que emergem de sua práxis, dentro de um processo formativo no próprio exercício da profissão, em que a ação coletiva se realimenta das discussões, pesquisas e debates. Nesta perspectiva: 
Medeiros, M. A. O., de Souza, V. O., da Silva, A. L. G., Relações étnico-raciais e de gênero em

A pesquisa-ação colaborativa tem por pressuposto, que os sujeitos que nela se envolvem compõem um grupo com objetivos e metas comuns, interessados em um problema que emerge num dado contexto [...] pesquisadores universitários e pesquisadores (professores no caso escolar) (PIMENTA, 2005, p. 523).

Assim, nessa relação entre pesquisador/a e docentes são estabelecidas teias de conexão na (re)construção de conhecimentos pois, nesse movimento de autoformação os/as docentes se tornam sujeitos/as colaborativos/as.

Observamos que ambas as investigações propõem a pesquisa com e não sobre, considerando os/as participantes como produtores/as, coautores/as, numa relação horizontalizada e colaborativa, em que cada sujeito/a olha para sua prática, reflete sobre ela e intervém no coletivo. Nesse caminho, relacionamos a "ética do cuidar", de Collins (2019), a uma ética do cuidado metodológico que sugere a "expressividade pessoal, as emoções e a empatia" como elementos centrais na construção do conhecimento, estabelecendo relação de reciprocidade e confiança com os/as colaboradores/as e as escolas em estudo.

Assim, compreendemos como os APs se interrelacionam nas duas pesquisas, pois seu modus operandi estabelece uma intervenção auto formativa que oportuniza ouvir e refletir as vozes dos/as sujeitos/as, num ciclo de ação-reflexãoação (SILVA e MEDEIROS, 2020). Está condizente com as especificidades das pesquisas de Mestrados Profissionais, com seu caráter implicado e engajado, na construção de saberes e conhecimentos que compreendem os sentidos apreendidos no grupo de discussão, rodas de debates, interação e troca de experiências, visando a intervenção. Da mesma forma as autoras afirmam:

O Ateliê de Pesquisa: é o lugar como espaço-tempo formativo auto formativo, cujo trabalho será produzido por pessoas/profissionais com vontade de criar e, onde se pode experimentar, manipular e produzir produtos resultantes da pesquisa como princípio educativo, cognitivo, formativo, colaborativo e de reflexão/avaliação constante sobre a prática pedagógica (SILVA; MEDEIROS, 2020, p.65).

Destacamos ainda que esse dispositivo tem uma natureza autoral, pois cada pesquisador/a imprime suas marcas pessoais, seu modo de fazer, ou seja, não é necessário fazer como, mas fazer com o outro/a. Nesse sentido, os AP's integraram os diários de bordo como dispositivo complementar que possibilitou a escrita de si 
Medeiros, M. A. O., de Souza, V. O., da Silva, A. L. G., Relações étnico-raciais e de gênero em debate nos Ateliês de Pesquisa: (Re)invenções nas Práticas Pedagógicas. ODEERE, v. 6, n. 01 , jan./jun., p. 311-341, 2021. https://doi.org/10.22481/odeere.v6i01.8581

pelos/as colaboradores/as, a construção de suas escrevivências, na pesquisa de SOUZA (2020), assim como nas demais pesquisas em que as narrativas orais e escritas nos diários de bordo foram produzidas e partilhadas no coletivo.

A partir dos diários os/as participantes narraram dúvidas, inquietações, saberes e não saberes, (des)construções e (re)significações, comunicando relatos de si, a partir de experiências e subjetividades produzidas no processo de formação, nas práticas cotidianas e em suas histórias de vida. Esses relatos foram compartilhados nos espaços dos APs, e possibilitaram refletir sobre seu processo (auto)formativo e suas práticas, avaliando-se e pensando possibilidades de qualificação do trabalho.

Nos APs o ponto de partida das discussões são os "modos de conhecer radicados na experiência" (HOOKS, 2017), os saberes e fazeres docentes, as "práticasteorias"6 que se produzem nas paisagens da escola. Abrimos espaço para estudos e discussões que provocam problematizações sobre nosso fazer frente às relações cotidianas, pois todos os/as agentes escolares têm pertencimentos de raça, gênero, sexualidade e outros.

Tanto na etnoescrevivência como na pesquisa ação colaborativa, as narrativas coautorais, impregnadas de pertencimentos, experiências, embebidas de nossas "praticasteorias" comunicaram modos de resistir aos padrões hegemônicos, mobilizando processos colaborativos e fortalecendo a produção de conhecimentos em rede. Ao narrar as práticas pedagógicas sobre as relações de raça e gênero, apontamos caminhos de significação e reflexão de experiências individuais e coletivas, e nos reinventamos como docentes inquietos/as e insubmissos/as diante das estruturas raciais e patriarcais.

\section{Trilha narrativa 3 - Experiências com AP's antes/e depois da pandemia: resultados centrais}

Inicialmente nos importa destacar que o uso dos Ateliês de Pesquisa data de 2014 e se expandiu nos últimos anos em pesquisas tanto internas ao programa de Pós-Graduação em Educação e Diversidade, como em pesquisas cujo raio de

6Sem dicotomizar como nos ensina Nilda Alves (2003) a fim de construir outros sentidos mais plurais e integrados. Ver referências completas ao final. 
Medeiros, M. A. O., de Souza, V. O., da Silva, A. L. G., Relações étnico-raciais e de gênero em debate nos Ateliês de Pesquisa: (Re)invençōes nas Práticas Pedagógicas. ODEERE, v. 6, n. 01 , jan./jun., p. 311-341, 2021. https://doi.org/10.22481/odeere.v6i01.8581

abrangência se ampliou para outros estados, como pesquisas apresentadas em São Paulo, Salvador, Jacobina, Conceição do Coité, Juazeiro, João Pessoa, Aracaju -SE, Lima - Peru, num total de 37 pesquisas. Destas, as publicações variaram em artigos em capítulos de livros, revistas, resumos expandidos em eventos nacionais e internacionais e relatórios de pesquisa (SILVA e SÁ, 2016). O quadro 1, nos apresenta os dados das produções que trazem os Ateliês de Pesquisa em dissertações sendo: 03 (2020); 04 (2018);01 (2019) 01 (2016) Jacobina (BA) 06; Conceição do Coité (BA) 01; Taubaté (SP) 01; relatórios: 01 (2017); 02 (2019); 02 (2020), num total de 21 produções.

Quadro 01 - Produções/Ateliês de Pesquisa - Dissertaçōes e relatórios

\begin{tabular}{|c|c|c|c|c|}
\hline Título & $\begin{array}{c}\text { Autor(a/as/ } \\
\text { es) }\end{array}$ & Ano & Programa/Universidade & Formato final \\
\hline $\begin{array}{l}\text { Imagensnarrativas das } \\
\text { práticas pedagógicas em } \\
\text { perspectiva de gênero: } \\
\text { tessituras cotidianistas }\end{array}$ & $\begin{array}{l}\text { Graciele } \\
\text { Mendes de } \\
\text { Carvalho }\end{array}$ & 2020 & $\begin{array}{l}\text { Mestrado Profissional } \\
\text { em Educação e } \\
\text { Diversidade/ UNEB } \\
\text { Campus XIV }\end{array}$ & $\begin{array}{l}\text { Imagens } \\
\text { narrativas/Disser } \\
\text { tação }\end{array}$ \\
\hline $\begin{array}{l}\text { Pedagogias feministas } \\
\text { sertanejas: cartografias de } \\
\text { práticas escolares }\end{array}$ & $\begin{array}{l}\text { Daniele } \\
\text { Lopes } \\
\text { Ferreira }\end{array}$ & 2020 & $\begin{array}{l}\text { Mestrado Profissional } \\
\text { em Educação e } \\
\text { Diversidade/ UNEB } \\
\text { Campus XIV }\end{array}$ & $\begin{array}{l}\text { Texto de } \\
\text { qualificação }\end{array}$ \\
\hline $\begin{array}{l}\text { Relações étnico-raciais e de } \\
\text { gênero no contexto das } \\
\text { práticas pedagógicas: } \\
\text { escrevivências } \\
\text { (re)invenções na Educação } \\
\text { Básica }\end{array}$ & $\begin{array}{l}\text { Vaneza } \\
\text { Oliveira de } \\
\text { Souza }\end{array}$ & 2020 & $\begin{array}{l}\text { Mestrado Profissional } \\
\text { em Educação e } \\
\text { Diversidade/ UNEB } \\
\text { Campus IV }\end{array}$ & $\begin{array}{l}\text { E- } \\
\text { book/dissertaçã } \\
\text { o }\end{array}$ \\
\hline $\begin{array}{l}\text { Pedagogia feminista no } \\
\text { território escolar: devires } \\
\text { cartográficos no } \\
\text { enfrentamento da violência } \\
\text { sexual infantil }\end{array}$ & $\begin{array}{l}\text { Laís Oliveira } \\
\text { Abreu }\end{array}$ & 2020 & $\begin{array}{l}\text { Mestrado Profissional } \\
\text { em Educação e } \\
\text { Diversidade/ UNEB } \\
\text { Campus IV }\end{array}$ & $\begin{array}{l}\text { Cartografia de } \\
\text { afetos/Dissertaç } \\
\text { ão }\end{array}$ \\
\hline $\begin{array}{l}\text { Base Nacional Comum } \\
\text { Curricular: apagamentos e } \\
\text { implicações da diversidade } \\
\text { na formação em exercício } \\
\text { da coordenação } \\
\text { pedagógica }\end{array}$ & $\begin{array}{l}\text { Fábia Alves } \\
\text { de Lima }\end{array}$ & 2020 & $\begin{array}{l}\text { Mestrado Profissional } \\
\text { em Educação e } \\
\text { Diversidade/ UNEB } \\
\text { Campus IV }\end{array}$ & $\begin{array}{l}\text { Texto de } \\
\text { qualificação }\end{array}$ \\
\hline
\end{tabular}


Medeiros, M. A. O., de Souza, V. O., da Silva, A. L. G., Relações étnico-raciais e de gênero em debate nos Ateliês de Pesquisa: (Re)invenções nas Práticas Pedagógicas. ODEERE, v. 6, n. 01 , jan./jun., p. 311-341, 2021 . https://doi.org/10.22481/odeere.v6i01.8581

\begin{tabular}{|c|c|c|c|c|}
\hline $\begin{array}{l}\text { Interseccionalidade no } \\
\text { entrelace da surdez e } \\
\text { sexualidade: o experimento } \\
\text { das cartografias corporais } \\
\text { na Educação Básica de } \\
\text { Jacobina/Bahia }\end{array}$ & $\begin{array}{l}\text { Ádina } \\
\text { Nunes Rios }\end{array}$ & 2020 & $\begin{array}{l}\text { Iniciação Cientifica/ } \\
\text { UNEB Campus IV }\end{array}$ & Relatório de IC \\
\hline $\begin{array}{l}\text { Gênero e formação } \\
\text { docente: cartografias da } \\
\text { prática pedagógica do } \\
\text { professor de } \\
\text { História em contextos de } \\
\text { diversidade na Educação } \\
\text { Básica de Jacobina-BA }\end{array}$ & $\begin{array}{ll}\text { Cruz } & \text { Saane } \\
\text { de } & \text { Souza } \\
\text { Cruz } & \end{array}$ & 2020 & $\begin{array}{l}\text { Iniciação Cientifica/ } \\
\text { UNEB Campus IV }\end{array}$ & Relatório de IC \\
\hline $\begin{array}{l}\text { Práticas discursivas } \\
\text { docentes sobre as } \\
\text { performances de gênero no } \\
\text { contexto escolar. }\end{array}$ & $\begin{array}{l}\text { Alisson } \\
\text { Esdras } \\
\text { Fernandes } \\
\text { de Oliveira }\end{array}$ & 2019 & $\begin{array}{l}\text { Mestrado Profissional } \\
\text { em Educação e } \\
\text { Diversidade/ } \\
\text { Campus IV }\end{array}$ & Dissertação \\
\hline $\begin{array}{lr}\text { Práticas pedagógicas em } \\
\text { contextos de diversidade na } \\
\text { educação básica de } \\
\text { Jacobina - } \\
\text { interseccionalidade } \\
\text { recursos multimídia }\end{array}$ & $\begin{array}{l}\text { Fernando } \\
\text { Macedo da } \\
\text { Silva }\end{array}$ & 2019 & $\begin{array}{l}\text { Iniciação Cientifica/ } \\
\text { UNEB Campus IV }\end{array}$ & Relatório de IC \\
\hline $\begin{array}{l}\text { A Educação Inclusiva na } \\
\text { construção da identidade } \\
\text { dos sujeitos surdos }\end{array}$ & $\begin{array}{l}\text { Ádina } \\
\text { Nunes Rios }\end{array}$ & 2019 & $\begin{array}{l}\text { Iniciação Cientifica/ } \\
\text { UNEB Campus IV }\end{array}$ & Relatório de IC \\
\hline $\begin{array}{l}\text { Ensino de história e cultura } \\
\text { afro-brasileira, africana e } \\
\text { identidade: desafios e } \\
\text { implicações nas práticas } \\
\text { pedagógicas }\end{array}$ & $\begin{array}{l}\text { Marleide } \\
\text { Alves de } \\
\text { Oliveira } \\
\text { Medeiros }\end{array}$ & 2018 & $\begin{array}{l}\text { Mestrado Profissional } \\
\text { em Educação e } \\
\text { Diversidade/ } \\
\text { Campus IV }\end{array}$ & Dissertação \\
\hline $\begin{array}{l}\text { Dissidências e (im) } \\
\text { pertinências de gênero no } \\
\text { território escolar: memorial } \\
\text { cartográfico }\end{array}$ & $\begin{array}{l}\text { Lucemberg } \\
\text { Rosa de } \\
\text { Oliveira }\end{array}$ & 2018 & $\begin{array}{l}\text { Mestrado Profissional } \\
\text { em Educação e } \\
\text { Diversidade/ } \\
\text { Campus IV }\end{array}$ & $\begin{array}{l}\text { Memorial } \\
\text { cartográfico } \\
\text { /dissertação }\end{array}$ \\
\hline $\begin{array}{l}\text { Peordenador } \\
\text { Pedagógico e a Diversidade } \\
\text { de Gênero na Formação de } \\
\text { Professores }\end{array}$ & $\begin{array}{l}\text { Thaísa } \\
\text { Rocha Reis }\end{array}$ & 2018 & $\begin{array}{lrr}\text { Programa } & \text { de } & \text { Pós- } \\
\text { graduação } & & \text { em } \\
\text { Educação } & & \text { da } \\
\text { Universidade } & & \text { de } \\
\text { Taubaté. } & & \end{array}$ & Dissertação \\
\hline $\begin{array}{l}\text { Educação sexual na } \\
\text { educação } \\
\text { formação em exásica: } \\
\text { práticas pedagógicas em } \\
\text { contextos de diversidades }\end{array}$ & $\begin{array}{l}\text { Fernando } \\
\text { Macedo da } \\
\text { Silva }\end{array}$ & 2017 & $\begin{array}{l}\text { Mestrado Profissional } \\
\text { em Educação e } \\
\text { Diversidade/ } \\
\text { Campus IV }\end{array}$ & Relatório IC \\
\hline $\begin{array}{l}\text { A educação sexual nos livros } \\
\text { didáticos de biologia: uma } \\
\text { abordagem no campo do } \\
\text { currículo }\end{array}$ & $\begin{array}{l}\text { Roberto } \\
\text { Santos } \\
\text { Teixeira Filho }\end{array}$ & 2016 & $\begin{array}{lr}\text { Mestrado Profissional } \\
\text { em Educação e } \\
\text { Diversidade/ } \\
\text { Campus IV }\end{array}$ & Dissertação \\
\hline
\end{tabular}

Fonte: Elaboração das autoras (2021). 
Medeiros, M. A. O., de Souza, V. O., da Silva, A. L. G., Relações étnico-raciais e de gênero em debate nos Ateliês de Pesquisa: (Re)invenções nas Práticas Pedagógicas. ODEERE, v. 6, n. 01 , jan./jun., p. 311 -341, 2021. https://doi.org/10.22481/odeere.v6i01.8581

Os dados evidenciam os Ateliês de Pesquisa como espaço fecundo de discussão em que muitos temas podem ser mobilizados, e que se alinham a muitos métodos investigativos. São "espaços tempos" de (auto) formação que nos desafiam à reflexividade, co criação e (re)inveção de nossos saberes e fazeres, em diferentes contextos de pesquisa e formação. As experiências com os APs nas pesquisas em tela convidaram professores/as a tecer juntos/as, em coautoria e colaboração. Assim, os APS foram desenvolvidos presencialmente até o final de 2019, e a partir de 2020, em função do distanciamento social, foi necessário realinhar e reajustar o dispositivo, através de movimentos de (re)invenção em virtude da pandemia de COVID-197.

A nova realidade convocou mudanças em nós, nas instituições e nas relações. No contexto da educação, foi necessário repensar a escola, a universidade e os modelos presenciais e buscar outras formas de ensinar, aprender, pesquisar, ampliando as redes de interação on-line e reconfigurando a paisagem para o espaço virtual. Os "espaçotempos" ganharam outros contornos para educar na cibercultura e nós aprendemos a usar as ferramentas da comunicação ubíqua a favor da formação e da pesquisa, através das interfaces online.

Fomos convocados/as a desenvolver estratégias e integrar outros modos de pensar a pesquisa, considerando as novas realidades, pois a pesquisa foi produzida com pessoas e pautou-se na ética do cuidado, na emoção, na experiência com sua vivacidade. Realizamos o realinhamento do dispositivo com cuidado ético e respeito às/aos colaboradoras/es. Nesse contexto, compreendemos que muitos desafios estavam postos: as dificuldades de operar com a tecnologia, a ausência do contato presencial, do toque, a preocupação com a interação e participação do grupo para que os objetivos fossem alcançados, o tempo de exposição na tela, o espaço do lar como ambiente dos encontros, e principalmente, a preocupação com a saúde e o bem estar físico e emocional de cada colaborador/a.

Por outro lado, observamos muitos ganhos, como a possibilidade de aproximação durante o período de distanciamento social, a integração de pessoas de diferentes e distantes territórios, que não teriam condição de participar

70 coronavírus apareceu pela primeira vez na China em 2019. Responsável pelo surgimento de uma infecção respiratória se espalhou por todo o mundo matando milhões de pessoas. A doença pode variar de uma simples gripe a sintomas muito graves, colocando a vida em risco e causando óbito. Para saber mais, consultar: https://www.tuasaude.com/coronavirus/. Acesso em 13.03.2021. 
Medeiros, M. A. O., de Souza, V. O., da Silva, A. L. G., Relações étnico-raciais e de gênero em debate nos Ateliês de Pesquisa: (Re)invenções nas Práticas Pedagógicas. ODEERE, v. 6, n. 01 , jan./jun., p. 311-341, 2021. https://doi.org/10.22481/odeere.v6i01.8581

presencialmente. Os APs online foram realizados em plataformas que permitiram interações síncronas entre participantes, nas quais era possível ver, falar, escrever, escutar e perceber gestos e reações. Esta interatividade era uma forma de aproximação, de dizer dos nossos sentimentos e inquietações, separadas/os territorialmente, mas conectadas/os pelo afeto, pelo olhar, pela escuta.

Na pesquisa de Souza $(2020$, p. 97, 98), a narrativa da professora Dandara em seu diário nos dá pistas de como esse movimento on-line foi deslocador, ao expor suas práticas no diálogo com o grupo.

\begin{abstract}
Eu ia escrever, mas decidi falar. O momento foi um momento muito rico, eu já coloquei aqui algumas vezes no chat, foi muito valioso, porque assim, eu fiquei no início um tanto com receio, porque é você abrir, você deixar o seu íntimo, por mais que foi uma experiência que todo mundo na escola viu, nós somos colegas, mas assim, é o olhar do outro e a gente ainda tem esse receio todo de mostrar nossas escritas, de mostrar o nosso fazer, a gente professor ainda é muito daquele lugar de: fechei a porta da minha sala sou eu aqui e meus alunos e acabou. Então é você se despir um pouco, você se mostrar mesmo, para os outros e mostrar sua escrita, e uma escrita de um lugar pessoal, então é muita intimidade. Mas o grupo foi muito generoso, e foi tão bom! [...] foi tão natural, foi tão prazeroso, tão enriquecedor [...] porque as vezes a gente tem que pensar assim, o que é que está bom que dá pra seguir adiante? Então, trouxe esse sentimento que tudo que a gente faz já é um bom começo que vale a pena ser melhorado e qualificado. E a agente está aqui pra isso, para melhorar, e os colegas com uma humildade tão grande foram dizendo o que estava bom e o que precisa melhorar, cuidando, cuidando, pra que a gente siga escrevendo, isso é muito bom, foi muito prazeroso (narrativa oral de Dandara, 2020) ${ }^{8}$.
\end{abstract}

Percebemos que a participante se mostra atravessada, trazendo memórias afetivas e reelaborando a experiência formativa que foi pautada na cogestão e na horizontalidade, não no julgamento. A docente expôs o prazer que sentiu ao refletir sobre a escrita e avançar na narrativa a partir das contribuições dos pares no intercâmbio (auto)formativo. Nessa avaliação, sentimos a ética do cuidado e o ethos da confiança em ação quando a professora compartilha a experiência e seus afetamentos.

Sabemos que falar ou escrever sobre si e suas práticas é desafiador, e quando essa escrita está exposta a outros olhares pode causar sentimentos de desconforto. O diferencial foi $\mathrm{O}$ agenciamento da confiança aliado à horizontalidade que o dispositivo convoca, a forma como a atividade foi

\footnotetext{
8 Na pesquisa de Souza (2020) os pseudônimos foram escolhidos pelos/as colaboradoras a fim de preservar suas identidades, conforme Resolução 510/2016.
} 
Medeiros, M. A. O., de Souza, V. O., da Silva, A. L. G., Relações étnico-raciais e de gênero em debate nos Ateliês de Pesquisa: (Re)invenções nas Práticas Pedagógicas. ODEERE, v. 6, n. 01 , jan./jun., p. 311 -341, 2021. https://doi.org/10.22481/odeere.v6i01.8581

encaminhada com base na colaboração, conhecer os objetivos do movimento (auto)formativo, a generosidade das/os colegas ao contribuir com a aprendizagem em rede, onde a escuta sensível e a ética do cuidado permearam a relação.

Outro aspecto que parece afetar de modo positivo a professora é perceber a valorização de seu trabalho com as relações de raça e gênero na escola, sua importância, motivo pelo qual merece ser discutida, conhecida, publicizada. Infelizmente, não é comum que professoras/es tenham suas experiências pedagógicas valorizadas em uma sociedade que está assistindo ataques sistemáticos à educação e às/aos educadoras/es.

Ao nos (re)inventar no espaço formativo on-line sentimos a potência do dispositivo, que movimentou o encontro como acontecimento e agenciou subjetividades e confiança no grupo. Ao trazer à discussão as relações étnicoraciais e de gênero, os encontros provocaram as/os docentes a relatar suas experiências e possibilitaram repensar seu fazer, através da problematização e intervenção mobilizadas pela inteligência coletiva e pelos interesses do grupo.

Refletindo sobre essas relações, um docente colaborador da pesquisa de Souza (2020) trouxe seus atravessamentos nos espaços de formação e da prática.

O fato de o ateliê de pesquisa acontecer concomitante com nossa prática pedagógica na sala de aula, todos aqueles debates inevitavelmente estavam presentes em minha mente e prática na sala de aula, mesmo entendendo os limites impostos para colocar em prática uma educação antirracista e antimachista (...)

Todos os encontros foram muito importantes no plano pessoal e profissional, pois, ao me sensibilizar ainda mais sobre o racismo e machismo, isso me fortaleceu enquanto profissional de educação, para que as reflexões não ficassem somente no plano do pensamento, mas nas práticas pedagógicas cotidianas (narrativa do diário de Ericco, 2020).

A narrativa mostra o processo de reflexão sobre a prática a partir das trocas nos APs. No espaço aberto à experimentação, ao diálogo, à reflexão, as partilhas entre colegas afetaram a prática pois convocaram a entrar em um movimento (auto)formativo para além do "plano do pensamento", provocando alteração no fazer docente, um processo de autorregulação do trabalho pedagógico sobre as relações de raça e gênero.

Através dos diálogos nos APs, a pesquisa de Souza (2020) apontou caminhos 
Medeiros, M. A. O., de Souza, V. O., da Silva, A. L. G., Relações étnico-raciais e de gênero em debate nos Ateliês de Pesquisa: (Re)invenções nas Práticas Pedagógicas. ODEERE, v. 6, n. 01 , jan./jun., p. 311-341, 2021. https://doi.org/10.22481/odeere.v6i01.8581

de reinvenção da escola e sua movimentação transitória de mudanças na educação das relações étnico-raciais, integrando também gênero. Os movimentos formativos afetaram professoras/es na construção de práticas pedagógicas e curriculares que transgridam hegemonias de raça e gênero, mobilizando processos de reflexão, reelaboração e descolonização do trabalho. As/os docentes colaboradoras/es narraram suas experiências com práticas pedagógicas insurgentes e mostraram-se abertas/os para escutar as estudantes, refletir sobre suas impressões e sugestões e reconfigurar essas práticas, (re)inventando seus modos de ser e estar na docência de forma autoral.

Permanecem como desafios principais na escola investigada em Iraquara$\mathrm{Ba}$, estabelecer diálogo entre as áreas do conhecimento e componentes curriculares, romper o currículo determinado, ampliar análises interseccionais e afetar mais professoras/es para a construção de práticas pedagógicas antirracistas e antissexistas como compromisso político durante todo ano letivo.

Os Ateliês na pesquisa de Medeiros (2018) representaram uma experiência inovadora de auto formação docente, aprofundando e dialogando com as categorias de estudo, a partir do seu objeto de pesquisa: Identidade, Ensino de História e Cultura Afro-brasileira e Formação Docente, juntamente com as práticas pedagógicas, uma categoria emergente, junto com várias subcategorias: racismo no cotidiano escolar, Interseccionalidades de raça, classe e gênero.

Dentre as conclusões, afirmaram que o racismo na escola existe, e precisa ser combatido, infere-se que é necessário trabalhar as questões de Identidade, sobretudo identidade negra. Destacou-se a necessidade de ensinar os direitos e as leis que defendem os/as alunos/as negros/as, e os conceitos pertinentes ao Ensino da Cultura e identidade e valorização dos povos negros, como também estabelecer ações para combater o racismo, assim como reiteramos na narrativa de uma colaboradora da pesquisa de Medeiros (2018, p. 170):

Porque é o seguinte: quando eu me considero uma professora não racista, não basta só falar que não é racista, ou como aquele que combate o racismo, que são duas coisas distintas. Você não precisa só se intitular, eu não sou racista, você precisa combater o racismo na escola (narrativa de SALETE, 2018).

[...] Cadê as leis que regem o nosso país, que defende o povo negro, qual é o professor que tá trabalhando? Pro aluno de fato ter conhecimento de seus direitos pra ele saber agir frente a casos de injúria racial e do racismo.[...] Para onde meu aluno negro vai? Se resume ele a uma comida a uma roupa 
Medeiros, M. A. O., de Souza, V. O., da Silva, A. L. G., Relações étnico-raciais e de gênero em debate nos Ateliês de Pesquisa: (Re)invenções nas Práticas Pedagógicas. ODEERE, v. 6, n. 01 , jan./jun., p. 311 -341, 2021 . https://doi.org/10.22481/odeere.v6i01.8581

colorida e uma dança, só isso? Isso é bonito? (narrativa de SALETE, 2018) 9 .

Debater o racismo institucional na educação, assinala o fato dos/as estudantes sofrerem desvantagens no acesso, inferiorização, estigmas de suas referências culturais, e o consequente fracasso (LIMA, 2015). Portanto, o currículo antirracista deve contestar as causas institucionais, históricas e discursivas do racismo, assim como não pode limitar-se a informações racionais, precisa se preocupar com a noção de representação e de poder em nossa sociedade (SILVA, 2017). Ao longo dos encontros demarcou-se a importância da Lei 10639 \03 para estabelecer uma educação antirracista, na qual dialogamos sobretudo com os trabalhos de Gomes (2012) e Lima (2015.)

Nesse sentido, a mudança estrutural proposta por essa legislação abre caminhos para a construção de uma educação antirracista que acarreta uma ruptura epistemológica e curricular, na medida em que torna público e legítimo o 'falar' sobre a questão afro-brasileira e africana. (GOMES, 2012, p.105).

Destaca-se na pesquisa (MEDEIROS, 2018) a relevância em trabalhar a Lei 10639\03 em todo âmbito escolar num processo de diálogo e crítica acerca da nossa realidade social, sobretudo nas questões do racismo. Nesta perspectiva, admitimos que saber discutir a história e a cultura afro-brasileira na escola, junto com alunos/nas, requer uma mudança de olhar para a sociedade, a família, os grupos sociais, atentando para as formas como se dão as relações raciais, lendo criticamente a mídia, a política, a cultura, os bairros, os/as trabalhadores/as, as elites, as imposições, as negações, as invisibilidades como a pessoa negra é vista e tratada na sociedade (LIMA, 2015). Assim, nosso trabalho, com direcionamentos para uma educação antirracista, deve envolver todos esses aspectos, com ênfase na leitura crítica de tudo que nos atravessa como sujeitos no contexto que vivemos.

Configurou-se um tema recorrente nos APs: a necessidade de formação contínua para trabalhar em sala de aula de forma fundamentada a lei 10.639/03 (MEDEIROS, 2018). Daí consolidamos o objetivo do produto da pesquisa: os Ciclos de formação, contemplando os eixos temáticos pertinentes, pois "não basta o reconhecimento da pluralidade, mas encontrarmos estratégias concretas, integradas, inclusivas, para traduzi-las no contexto escolar" (IVENICKI, 2015, p.131).

9 Nome fictício dos/as colaboradores/as da pesquisa de Medeiros (2018). 
Medeiros, M. A. O., de Souza, V. O., da Silva, A. L. G., Relações étnico-raciais e de gênero em

Portanto, a partir das narrativas e discussões dos/as colaboradores/as, a ideia dos Ciclos de Formação foram consolidando-se nos Ateliês, pois todos/as docentes compreenderam a necessidade de formação para ampliar conhecimentos sobre a educação para diversidades (MEDEIROS, 2018). Portanto, um dos produtos da pesquisa, "Os Ciclos de Formação", se constituiu numa proposta de formação docente em exercício, no próprio lócus da escola, baseada na reflexividade da prática na prática, a qual foi elaborada, descrita e apresentada aos representantes municipais, para dar continuidade aos desdobramentos pós-defesa tendo as demandas do cotidiano escolar como ponto de partida-chegada.

Dessa forma, com a intenção de cartografar as pistas sobre as reflexões, discursos e práticas pedagógicas no que tange ao contexto da Educação Inclusiva, os Ateliês dos Ciclos de formação englobaram em seu desenvolvimento, além dos desdobramentos de Medeiros (2018), da contribuição da pesquisa de Sena (2018) e da participação de pesquisadores/as de IC, se configuraram como espaços de construção e desconstrução coletiva e colaborativa, promovendo os debates sobre os contextos de diferença. Assim, além das relações de raça e gênero, emergiram discussões sobre sexualidades, surdez, inclusão de pessoas com deficiência, além de multiletramentos, alfabetização e aprendizagem.

Os Ateliês de Pesquisa realizados pelos/as estudantes de graduação em subprojeto de IC, mencionados na introdução deste artigo, revelaram ser potentes dispositivos para o trabalho com as diversidades, o que possibilitou discutir as práticas pedagógicas, na perspectiva das pluralidades dos sujeitos envolvidos no processo de ensino e aprendizagem e suas múltiplas identidades. A pesquisa de Fernando Macedo (2018-2019), que engloba e amplia os estudos e discussões sobre gênero e diversidades apresenta, como principal resultado, que as reflexões das professoras em seus diários de bordo sinalizam a importância dos temas da diversidade na educação como relevante, necessária e urgente. Assim como construiu um material midiático valioso para estudos sobre a diversidade.

A pesquisa de Ádina Rios (2019) apresentou como objetivo compreender as principais contribuições apresentadas pela prática pedagógica docente e suas influências no processo da construção identitária dos sujeitos no contexto da surdez. Desta forma, trouxe aos/às docentes percepções abrangentes e propiciou 
Medeiros, M. A. O., de Souza, V. O., da Silva, A. L. G., Relações étnico-raciais e de gênero em debate nos Ateliês de Pesquisa: (Re)invenções nas Práticas Pedagógicas. ODEERE, v. 6, n. 01 , jan./jun., p. 311-341, 2021. https://doi.org/10.22481/odeere.v6i01.8581

importantes discussões sobre formação e docência. Os principais resultados apontam a compreensão dos/as docentes sobre a relevância de tratar de temas como diversidades, inclusão e a importância do debate, da revisão das práticas pedagógicas, e a necessidade de repensar e reelaborar os planejamentos pedagógicos, currículos escolares, numa perspectiva crítica, com ênfase na formação e reflexão da prática.

Os dois projetos de pesquisa que se seguiram em contribuição aos ciclos, ocorreram durante a pandemia do Covid 19 e foram adequados ao novo formato, os Ateliês de Pesquisa on-line, o que redimensionou as experiências e possibilitou a participação de colaboradoras de outras cidades e escolas, dialogando com o grupo participante do Comuja. As estudantes e pesquisadoras, Ádina Rios (2019) e Renata Cruz (2020), com seus respectivos subprojetos, realizados on-line, apresentaram como resultados, reflexões e experiências sobre questões da diversidade e sobretudo da formação.

Cabe ressaltar as (in)conclusões tecidas na pesquisa on-line de Rios (2019), pela dinâmica de nuvem de palavras que sintetizam a concepção das docentes a respeito dos Ciclos de Formação e os sentidos dos Ateliês de pesquisa. Apontam as palavras em destaque, o acolhimento, a formação, a cartografia e o ethos da confiança, como as mais citadas pelo coletivo.

A pesquisa de Cruz (2020), nos ciclos on-line, toma como objeto de estudo as práticas pedagógicas nas aulas de História da Educação Básica, no Ensino Fundamental 2, considerando a abordagem de gênero em contextos de diversidade e suas implicações para a reflexividade da/na prática, e apresentou como resultados centrais que, a complexidade do contexto educacional se configura nas vivências e ações dos sujeitos em suas realidades e fazem emergir outros de modo interseccionado, tais como raça, classe, sexualidade, que aparecem de modo desafiador nas narrativas cartográficas das docentes. A categoria Interseccionalidade está presente em todas as pesquisas, o que demonstra o entrecruzar de todas as diversidades, e, portanto, corrobora a necessidade dos/as pesquisadores/as ampliarem as discussões nos Ateliês, visto que, inevitavelmente, outras questões e reflexões permeiaram a roda de debates.

Em síntese, o que nos ensinaram os Ateliês de pesquisa sobre os pontos de vistas dos sujeitos colaboradores da pesquisa acerca das nossas práticas 
Medeiros, M. A. O., de Souza, V. O., da Silva, A. L. G., Relações étnico-raciais e de gênero em

debate nos Ateliês de Pesquisa: (Re)invenções nas Práticas Pedagógicas. ODEERE, v. 6, n. 01 , jan./jun., p. 311-341, 2021. https://doi.org/10.22481/odeere.v6i01.8581

pedagógicas e reinvenções de si?

Novos modos de habitar a docência - movimento de estar-sendo docente sempre em devir;

Implicações das identidades docente, ou melhor, dos processos identitários fluidos, para o seu desenvolvimento profissional;

Condições de trabalho;

Dimensão política da docência;

As práticas pedagógicas no contexto escolar - escola como lócus da formação;

Universidade e educação básica em rede colaborativa na tecitura da formação docente;

As práticas pedagógicas requerem ações interventivas pois a docência é uma prática social;

Imersão na experiência;

Narrar sua prática e realizar a reflexividade da mesma;

Sair de si para vivenciar a experiência com o outro num movimento colaborativo em que a circularidade seja a centralidade;

Pesquisa-intervenção com um mergulho na experiência das/os docentes e nas demandas da escola;

Plano coletivo heterogêneo;

Respostas à pluralidade;

Experiência que transcende para a reflexão da prática - conhecimento pedagógico da prática e os saberes docentes;

Mobiliza, transforma, relendo a narrativa para observar o que a prática está comunicando; quais aprendizagens suscitaram; [quais contornos teóricos ajudaram na reflexão?];

Escrita autoral - teoria encarnada e implicada na experiência relatadao que fiz, o que posso alterar na minha prática;

Ao trabalhar com as diversidades somos interpelados/as a mobilizar diferentes competências que envolvem: saberes, cognição, sensibilidade e afetividade ${ }^{10}$. 
Medeiros, M. A. O., de Souza, V. O., da Silva, A. L. G., Relações étnico-raciais e de gênero em debate nos Ateliês de Pesquisa: (Re)invenções nas Práticas Pedagógicas. ODEERE, v. 6, n. 01 , jan./jun., p. 311-341, 2021. https://doi.org/10.22481/odeere.v6i01.8581

Esses princípios de reflexão, ação, intervenção pautados na experiência e na horizontalidade foram mobilizados nas duas pesquisas de mestrado, e nas pesquisas de Iniciação Científica, possibilitando mudanças nas práticas pedagógicas sobre as relações étnico-raciais e de gênero. No trabalho com as diversidades e diferenças emergem as interseccionalidades e provocam a problematização da prática. Assim, tanto no decorrer das pesquisas, como nos seus desdobramentos, observamos deslocamentos e abertura de caminhos de alteração das paisagens das escolas lócus, na busca por uma educação antirracista, antissexista e antidiscriminatória.

Os desdobramentos da pesquisa de Medeiros (2018) foram significativos no tocante às reflexões e práticas docentes; no ano de defesa, os/as professores/as colaboradores/as juntamente com seus pares, desenvolveram estudos, atividades ao longo das unidades letivas sobre as questões étnico-raciais, culminando num excelente trabalho de debates, apresentações e produções, fruto da construção coletiva, como também não ficou restrito apenas ao momento da pesquisa.

Outro desdobramento consistiu na efetivação dos Ciclos de Formação, produto autoral de sua pesquisa, o qual foi ampliado e abordou outros temas da diversidade contemplando além da Lei 10.639/03 e a educação antirracista, as questões de gênero, sexualidade e inclusão. Para tanto, foram incorporadas as quatro pesquisas de IC, no bojo das discussões dos APs, seja presencial ou on-line, e foram contemplados/as vários/as docentes da unidade escolar e de outras cidades, trazendo muitos olhares e contribuições para a potência que constitui os Ateliês de Pesquisa, enquanto espaço de fala, escuta, reflexão das práticas e produção de saberes e conhecimentos. O AP é a formação pela leitura, escrita, narratividade e (des)construção de práticas pedagógicas.

Muitas foram as influências e ressonâncias dos Ateliês, inclusive o incentivo aos/às docentes da educação básica em investirem no seu desenvolvimento profissional, participando da seleção do MPED, quer seja como aluno/a especial, ou como aluno/a regular, motivados/as pelas trocas de experiências e auxílio nos direcionamentos dos projetos de pesquisa, do mesmo modo que foram publicados relatórios, capítulo de livro e artigos em periódicos, fruto das pesquisas e seus resultados e relevância para o campo da educação. Destaca-se também a inspiração para outras pesquisas do programa, que citam os nossos ateliês como 
Medeiros, M. A. O., de Souza, V. O., da Silva, A. L. G., Relações étnico-raciais e de gênero em debate nos Ateliês de Pesquisa: (Re)invenções nas Práticas Pedagógicas. ODEERE, v. 6, n. 01 , jan./jun., p. 311-341, 2021. https://doi.org/10.22481/odeere.v6i01.8581

base para a produção de novas investigações e escritas.

Os desdobramentos da pesquisa de SOUZA (2020) incluíram o realinhamento do Projeto Institucional da escola sobre as relações étnico-raciais, para pautar a história e formação negra e indígena de Iraquara-Bahia, ouvindo as vozes dos grupos que compõem o município. Essa proposta surgiu das discussões com estudantes e professores/as da escola no interior da pesquisa e seu expresso interesse em conhecer suas origens a partir de narrativas contra-hegemônicas. As discussões e planejamentos aconteceram na jornada pedagógica, e os/as docentes seguiram planejando e ajustando o currículo anual com o intuito integrar a educação das relações étnico-raciais e de gênero nas práticas pedagógicas ao longo do ano letivo, de forma coletiva e interdisciplinar.

Além disso, durante a pandemia do COVID-19, a escola planejou salas temáticas com temas como gênero, sexualidades e racismo. Uma das salas, com o tema Racismo e intolerância, teve adesão de um expressivo grupo de estudantes e da comunidade externa, egressas/os, professoras/es de outras escolas, mães de estudantes e comunidade em geral. $O$ debate ganhou visibilidade no contexto da pandemia, com a explosão de casos de violência policial e manifestações de racismo gravadas e publicizadas na mídia (SOUZA, 2020).

As lives incluíram discussões sobre violência policial e os movimentos antirracistas; debates sobre negritudes e pertencimentos étnico-raciais; problematização de atitudes e discursos racistas; posicionamentos antirracistas; disseminação de imagens e estereótipos racistas através da mídia e da internet; indicação de material sobre protagonismo negro na literatura, filmes, páginas de internet, redes sociais; realização de atividades nos espaços virtuais de aprendizagem; divulgação de produções nas redes; discussão sobre ocupação de espaços de intelectualidade, decisão e poder; diálogo com egressos/as e estudantes de universidades.

Ainda nos desdobramentos da pesquisa de Souza (2020), foi construído um Coletivo de mulheres na cidade de Iraquara-Bahia. Este coletivo é estruturado nos princípios do feminismo negro, que coloca experiência, emoção e ética do cuidado como motes para pensar as relações e construir caminhos de empoderamento individual e coletivo. Os encontros do coletivo acontecem quinzenalmente desde abril de 2021. Nesse espaço, são mobilizadas discussões 
Medeiros, M. A. O., de Souza, V. O., da Silva, A. L. G., Relações étnico-raciais e de gênero em

sobre negritudes, pertencimentos, racismo, sexismo, interseccionalidades, realidades específicas das mulheres negras, feminismos, e outros, com base em autoras negras como Audre Lord, bell hooks, Djamila Ribeiro, Angela Davis, Carla Akotirene, e outras.

Este é um movimento de intervenção direta com mulheres e mulheres negras, onde aprofundamos discussões de interesse do grupo, estabelecendo momentos (auto)formativos através do acolhimento, da escuta sensivel, apoio, aproximação, troca de experiências, incentivo, valorização, estudos, discussões, movimento e fruição, que são intensificados na vivência com aquelas que experimentam os atravessamentos da raça e do gênero em suas experiências cotidianas.

As pesquisas mostraram resultados fecundos ao mobilizar os/as colaboradores para a formação em exercício e a reflexividade sobre a prática, tomando as experiências com as relações étnico-raciais e de gênero como centralidade. Os desdobramentos evidenciam que as ações no lócus extrapolaram o tempo de duração das investigações, atravessaram movimento reflexivo e (auto)formativo, mobilizaram outras autorias nas práticas pedagógicas.

\section{Trilhas finais}

Nas pesquisas em tela os resultados apontaram os APs como "espaçotempos" capazes de mobilizar experiências docentes, histórias de vida e formação profissional sobre as relações de raça, gênero e outras. É um espaço fecundo de mobilização e discussão que se alinha a muitos métodos investigativos e contextos de pesquisa e formação, por seu caráter dinâmico, autoral, interventivo.

Seus princípios permitiram realinhar e reajustar o dispositivo, através de movimentos de (re)invenção no contexto da pandemia de COVID-19, sem prejuízo do potencial formativo. Ao usar as ferramentas da comunicação ubíqua a favor da formação e da pesquisa, os APs possibilitaram outros encontros, com outros/as agentes, ampliando as redes de interação para/no espaço virtual.

Os APs se configuraram ainda, nas pesquisas analisadas, como espaços formativos horizontalizados e colaborativos, onde pautamos discussões com e a partir das/os agentes que habitam e produzem os cotidianos da escola. Ao agenciar o ethos da confiança e a ética do cuidado, os/as colaboradores/as 
Medeiros, M. A. O., de Souza, V. O., da Silva, A. L. G., Relações étnico-raciais e de gênero em

foram convidados/as à co criação e co autoria, um processo de invenção e experiências ancoradas no real do cotidiano escolar como propulsoras da produção do conhecimento pedagógico considerado como conhecimento científico do campo da docência.

Nesses espaços de formação e auto formação as narrativas da experiência, tanto orais como escritas, ganharam centralidade e provocaram deslocamentos nos saberes e fazeres docentes. Ao compreender que o desenvolvimento profissional da docência é sempre interrogado pela diversidade e pelas diferenças, emergiram reflexões sobre relações de raça e gênero, além de classe, sexualidade, deficiência, e a forma como esses eixos atravessam as relações escolares, muitas vezes interseccionados nas experiências de alunos/as e professoras/es.

Refletimos sobre a visão colonialista, estereotipada, sobre o epistemicídio e todas as formas de apagamentos das contribuições dos povos negros e mulheres negras em nossa formação escolar e acadêmica. Dialogamos sobre algumas práticas pedagógicas insurgentes que os/as docentes já desenvolvem e sua importância para desnaturalizar relações, posturas e atitudes discriminatórias, para questionar ideias racistas, sexistas que desmotivam ou excluem as/os alunas/os dentro ou fora da escola. Essa preocupação pode se materializar em nossas práticas curriculares e pedagógicas cotidianas quando trazemos narrativas que provocam a construção de imagens positivas e o protagonismo desses grupos.

Compreendemos que não basta sermos apenas antirracistas ou apenas antissexistas, é necessário estarmos dispostos/as a lutar contra todas as formas de discriminação na escola e em outros espaços. Apesar de centrarmos este texto na discussão sobre as relações de raça e gênero, compreendemos que todas as formas de opressão que emergiram precisam ser enfrentadas para que as/os estudantes compreendam o caráter produzido dos lugares sociais que ocupamos e questionem as estruturas, exercitando a consciência coletiva e o acolhimento nas avenidas onde seus/nossos corpos são alvejados por diferentes discriminações.

Perceber a natureza de tais relações exige sensibilidade analítica e muitas problematizações. Por isso, os APs mobilizaram discussões sobre a forma interseccional como as discriminações se apresentam, afetando corpos subalternizados de modo simultâneo e produzindo desigualdades e diferentes formas de exclusão. Esse olhar para as dinâmicas escolares contribuiu para 
Medeiros, M. A. O., de Souza, V. O., da Silva, A. L. G., Relações étnico-raciais e de gênero em debate nos Ateliês de Pesquisa: (Re)invenções nas Práticas Pedagógicas. ODEERE, v. 6, n. 01 , jan./jun., p. 311-341, 2021. https://doi.org/10.22481/odeere.v6i01.8581

descolonizar práticas pedagógicas e curriculares, uma vez que possibilita perceber os efeitos que conteúdos, práticas, metodologias de ensino, materiais didáticos, discursos e posicionamentos podem ter sobre as/os estudantes quando privilegiam a produção e disseminação de valores e conhecimentos que desconsideram as diferenças raciais, de gênero, sexualidade, dentre outras.

As discussões provocaram ainda deslocamentos nos processos formativos, produzindo alteração nas práticas pedagógicas. Apesar dos desafios em efetivar a educação antirracista, antissexista e antidiscriminatória de forma consistente e permanente, pequenas insurgências foram mobilizadas em direção a um modelo de escola que rejeita o controle dos corpos e a manutenção de relações hierarquizadas e excludentes. As pesquisas vêm contribuindo para ampliar processos formativos nas escolas lócus, evidenciando a potência da parceria entre universidade e educação básica. Tanto os Ciclos formativos, o coletivo de mulheres, como as pesquisas de Iniciação científica são ações que dão consistência ao trabalho, mostrando que as pesquisas nos Mestrados Profissionais vão muito além dos dois anos de imersão e até dos 2 anos de acompanhamento de campo, pois seus efeitos podem se propagar sobre os espaços e pessoas através de suas experiências formativas.

As produções publicadas, a participação dos/as colaboradores/as nos grupos de pesquisa, nas seleções de mestrado, a inserção como alunas regulares ou especiais, são também indicativos de resultados das pesquisas. Assim, expandimos o raio de abrangência das formações e das pesquisas fortalecendo parcerias e movimentos colaborativos na educação das relações étnico-raciais, de gênero e outras diferenças.

Ademais, os resultados que emergiram nas pesquisas analisadas indicam que as pesquisadoras e sujeitos/as da pesquisa criam os Ateliês de Pesquisa de modo inventivo e autoral, inundando o campo educacional de pesquisas que fazem brotar narrativas em que as escrevivências e histórias de vida balizam a produção do conhecimento como invenção de si e do outro numa comunidade científica de aprendizagem, cujas redes são tecidas com docentes da universidade e da educação básica de modo horizontalizado, tomando a experiência como formação. 
Medeiros, M. A. O., de Souza, V. O., da Silva, A. L. G., Relações étnico-raciais e de gênero em debate nos Ateliês de Pesquisa: (Re)invençōes nas Práticas Pedagógicas. ODEERE, v. 6, n. 01 , jan./jun., p. 311-341, 2021. https://doi.org/10.22481/odeere.v6i01.8581

\section{Referências}

ALVES, Nilda. Cultura e cotidiano escolar. Rev. Brasileira de Educação, n. 23, p. 6274, 2003.

AKOTIRENE, Carla. O que é interseccionalidade. Belo Horizonte: Letramento, 2018.

CARVALHO, Graciele Mendes de. Imagens narrativas das práticas pedagógicas em perspectiva de gênero: tessituras cotidianistas. Dissertação (Mestrado Profissional em Educação e Diversidade) - Universidade do Estado da Bahia. Conceição do Coité, p. 127. 2020.

CAVALLEIRO, Eliane. Do silêncio do lar ao silêncio escolar: racismo, preconceito e discriminação na educação infantil. 6. ed. São Paulo: Contexto, 2020.

COLLINS. Patrícia Hill. Pensamento feminista negro: conhecimento, consciência e a política do empoderamento. Tradução de Jamile Pinheiro Dias. São Paulo: Boitempo, 2019.

CRENSHAW, Kimberlé. Documento para o encontro de especialistas em aspectos da discriminação racial relativos ao gênero. Estudos Feministas, n. 171, 2002a. Disponível em: www.scielo.br/pdf/ref/v10n1/11636.pdf. Acesso em: 20 abr. 2017.

CRUZ, Renata Saane de Souza. Gênero e formação docente: cartografias da prática pedagógica do professor de História em contextos de diversidade na Educação Básica de Jacobina-BA. Relatório. Jacobina. 2020. 35 p.

EVARISTO, Conceição. Literatura negra: uma poética de nossa afro-brasilidade. SCRIPTA, Belo Horizonte, v. 13, n. 25, p. 17-31, 2009.

FERREIRA, Daniele. Pedagogias feministas sertanejas: cartografias de práticas escolares. Texto de qualificação. (Mestrado Profissional em Educação e Diversidade) - Universidade do Estado da Bahia. Conceição do Coité, p. 75. 2020.

GOMES, Nilma. Lino. Relações Étnico-Raciais, Educação e Descolonização dos Currículos. Currículo sem Fronteiras, v.12, n.1, pp. 98-109, Jan/Abr 2012

HOOKS, Bell. Ensinando a transgredir: A educação como prática da liberdade. São Paulo: WMF Martins Fontes, 2017. 
Medeiros, M. A. O., de Souza, V. O., da Silva, A. L. G., Relações étnico-raciais e de gênero em debate nos Ateliês de Pesquisa: (Re)invenções nas Práticas Pedagógicas. ODEERE, v. 6, n. 01 , jan./jun., p. 311-341, 2021 . https://doi.org/10.22481/odeere.v6i01.8581

IVENICKI, Ana. Políticas Educacionais e Diversidade na Escola: Desafios da/na Diversidade, In: RIOS, Jane Adriana Vasconcelos Pacheco (Org.). Políticas, práticas e formação na educação básica. Salvador: EDUFBA, 2015. p.129-134.

LARROSA, Jorge. Nietzsche \& a educação. Belo Horizonte: Autêntica, 2. ed. $1^{a}$. reimp., 2005.

LARROSA, Jorge. Notas sobre a experiência e o saber de experiência. Palestra proferida no $13^{\circ}$. COLE - Congresso de Leitura do Brasil. Unicamp, Campinas - SP, $2001 . \quad$ Disponível em: http://www.miniweb.com.br/Atualidade/INFO/textos/saber.htm. Acesso em: $13 / 6 / 2021$.

LIMA. Maria Nazaré de Mota. Relações étnico-raciais na escola: o papel das linguagens. Salvador: EDUNEB, 2015.

LOURO, Guacira Lopes. Gênero, sexualidade e educação: uma perspectiva pósestruturalista. Petrópolis: Vozes, 1997. p. 14-36.

MEDEIROS, Marleide Alves de Oliveira. Ensino de História e Cultura Afro-brasileira, Africana e Identidade: desafios e implicações nas Práticas pedagógicas. Dissertação (Mestrado Profissional em Educação e Diversidade) - Universidade do Estado da Bahia. Jacobina, p. 193. 2018.

PIMENTA, Selma Garrido. Pesquisa-ação crítico-colaborativa: construindo seu significado a partir de experiências com a formação docente Universidade de São Paulo. Educação e Pesquisa, São Paulo, v. 31, n. 3, p. 521-539, set./dez. 2005.

PIRES, Tânia Cavalcante; MIRANDA, Carmélia Aparecida da Silva. Relações étnicoraciais: uma abordagem escolar. Interfaces Científicas - Humanas e Sociais, Aracaju, v. 4, ed. esp. Contextos da Cultura, p. 143-153, 2015.

RIOS, Ádina Nunes. Interseccionalidade no entrelace da surdez e sexualidade: o experimento das cartografias corporais na Educação Básica de Jacobina/Bahia. Relatório. Jacobina. 2020. 30 p.

RIOS, Ádina Nunes. A Educação Inclusiva na construção da identidade dos sujeitos surdos. Relatório. Jacobina. 2019. 42 p. 
Medeiros, M. A. O., de Souza, V. O., da Silva, A. L. G., Relações étnico-raciais e de gênero em debate nos Ateliês de Pesquisa: (Re)invenções nas Práticas Pedagógicas. ODEERE, v. 6, n. 01 , jan./jun., p. 311-341, 2021. https://doi.org/10.22481/odeere.v6i01.8581

RIOS, Ádina Nunes; SILVA, Ana Lúcia Gomes da Silva. Educação inclusiva e surdez: desdobramentos do ateliê de pesquisa como dispositivo de construção de dados no contexto escolar. In: I Seminário Internacional Juventudes e Educação: cenários educacionais em tempos de reformas. 1., 2020, Juazeiro. Anais eletrônicos. Juazeiro: UNIVASF. 2020. p. 01-12. Disponível em: https://even3.blob.core.windows.net/anais/239709.pdf. Acesso em 26 mar. 2021.

SENA, Jaqueline Valois Rios. Textos no contexto de Ciências: letramento científico em pauta. 2018, 165 fls. Relatório Final de Pesquisa (Mestrado Profissional em Educação e Diversidade) - Universidade Estadual da Bahia. Jacobina-Bahia

SILVA, Ana Lúcia Gomes da. Ateliês de Pesquisa como método nas pesquisas implicadas com/na educação básica: sentidos propositivos dos estudos em educação e ensino de história. Salvador: 2021 [prelo].

SILVA, Ana Lúcia Gomes da; COSTA, Váldina Gonçalves da. O método cartográfico na pesquisa em educação: ateliê de pesquisa como dispositivo formativo. In: SILVA, Ana Lúcia Gomes da. et. al. (Orgs.). Ateliês de Pesquisa: formação de professores(as)-pesquisadores(as) e métodos de pesquisa em educação. 1. ed. Salvador: Eduneb, 2020. p. 57-142.

SILVA, Ana Lúcia Gomes da; MEDEIROS, Marleide Alves Oliveira de. Ateliê de pesquisa na construção colaborativa do conhecimento. In: ARAÚJO, Raimundo Dutra de; ARAUJO, Francisco Antônio Machado. (Orgs.). Processos metodológicos na pesquisa em educação: dispositivos de produção e análise de dados em movimento. 1. ed. Parnaíba: Acadêmica Editorial, 2020. p. 123-140.

SILVA, Ana Lúcia Gomes da; SÁ, Maria Roseli Gomes de Brito. Mestrado profissional: cenários e singularidades em intervenções na educação. Plurais Revista Multidisciplinar. Salvador, v. 1, n. 1, p. 59-71, jan./abr. 2016. Disponível em: https://www.revistas.uneb.br/index.php/plurais/article/view/2302/1606. Acesso em 27 mar. 2021.

SILVA, Fernando Macedo da. Práticas pedagógicas em contextos de diversidade na educação básica de Jacobina - BA: interseccionalidade e recursos multimídia. Relatório. Jacobina. 2019. 25 p. 
Medeiros, M. A. O., de Souza, V. O., da Silva, A. L. G., Relações étnico-raciais e de gênero em debate nos Ateliês de Pesquisa: (Re)invenções nas Práticas Pedagógicas. ODEERE, v. 6, n. 01 , jan./jun., p. 311-341, 2021. https://doi.org/10.22481/odeere.v6i01.8581

SILVA, Fernando Macedo da. Educação Sexual na Educação Básica: formação em exercício, práticas pedagógicas em contextos de diversidades. Relatório. Jacobina. 2017. 19 p.

SOUZA, Vaneza Oliveira de. Relações étnico-raciais e de gênero no contexto das práticas pedagógicas: escrevivências e (re)invenções na educação básica. Dissertação (Mestrado Profissional em Educação e Diversidade) - Universidade do Estado da Bahia. Jacobina, p. 239. 2020.

SOUZA, Vaneza Oliveira de; MIRANDA, Carmélia Aparecida da Silva; SILVA, Ana Lúcia Gomes da. Escrevivências e movimentos (auto)formativos na pesquisa por uma educação antirracista. Revell Revista de Estudos Literários da UEMS, v. 1, n. 24, 2020 .

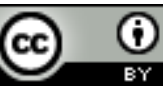

This work is licensed under a Licence Creative Commons Attribution 4.0 International License.

Este trabalho está licenciado com uma Licença Creative Commons - Atribuição 4.0 Internacional. 